\title{
Spa and Wellness Tourism in Poland - A New Geographical Analysis
}

\section{Krzysztof Widawski}

e-mail: krzysztof.widawski@wr.edu.pl

Department of Regional Geography and Tourism, Institute of geography and Regional Development, University of Wroclaw, Wroclaw, Poland

Widawski, K. (2017). Spa and Wellness Tourism in Poland - A New Geographical Analysis. Czech Journal of Tourism, 6(1), 69-92. DOI: 10.1515/cjot-2017-0004.

\begin{abstract}
The aim of the paper is to present the situation of the spa resorts in Poland from the geographical point of view, emphasizing especially the tourist context of their existence. This article firstly deals with the brief history of spas in Poland and the definition of the phenomenon, presented in the Polish literature and legal acts. The main part of the paper presents the geographical analysis of the phenomenon: spatial distribution of the activities allowed by law, localization concerning the different kind of landscapes that accompanies the spas, natural and curative resources and the medical treatments based on their potential. In addition, the tourist context analysed with the support of the statistical data of the accommodation units, tourist sand its preferences, and health tourist establishments in the spa resorts and its usage is also crucial. The perspectives of the spa tourism development in Poland concerning the potential and obstacles are presented.
\end{abstract}

\section{Keywords}

Spa, tourism, geographical analysis, health tourist establishments

JEL classification: I13, L83, Q26 


\section{Introduction}

Spa tourism is one of the oldest forms of tourism practiced in the world. Its beginnings have to be searched in the remote times of the Roman empire. Such popular names like French Vichy or English Bath derive from the first century (Iwanek \& Widawski, 2007). Although their popularity decreased during the following centuries, it was always present in the leisure offer. The Middle Ages were a starting point of spa tourism in the south west part of Poland - Lower Silesia. The spa offer has gained its followers throughout the centuries and the spa centers in their spatial shape started in XIX century and developed in the next century. At present, Poland is one of the most popular destinations in Central Europe. Spa tourism is one of the most attractive forms of tourism here. It does not necessarily concern numbers, but it has a wide material potential like spa infrastructure, natural spa resources and the long tradition of visiting the spa centers. Poland can offer 45 different licensed spa destinations that could attract both visitors searching for particular treatment for their disease, as well as tourists looking for different tourist values, including spa for the wellness purposes. These values together with the supporting infrastructure make out of the spa centers one of the most attractive destinations for tourism. Such statements are quite obvious, therefore, it would be interesting to analyze the present situation of spas in Poland as far as their potential is concerned (in absolute numbers; capacity and usage of health establishments; number of spa visitors, presentation of the offer with its characteristics; different categorizations and their structure together with the spatial distribution in the country). Thus, the summary developmental perspectives will be presented briefly together with potential problems that could influence the direction of changes.

\section{Brief history of spas in Poland}

The first information about the spa resorts in Poland appeared at the beginning of the 13th century. The act of granting the mineral waters in Cieplice and Lądek Zdrój for the Knights of the Order of St. John of Jerusalem was issued in 1221 (Balińska, 1991; Paprzycka, 2007). The next centuries is a period of growing popularity of the already existing spas and founding new spas - in the 15th century Iwonicz, Drużbaki, Lubień, Inowrocław and Swoszowice appeared on the spa map of Poland. Within two hundred years, the spa visits popularity increased in every region of Poland: the spa patients visited Kudowa Spa or Duszniki Spa in the mountainous region of the Sudetes and Kołobrzeg at the Baltic Sea or Ciechocinek and Nałęczów in the Lowland regions. In the 19th century the mentioned group was enlarged by Goczałkowice, Jastrzębie, Polanica, Szczawno, Kamień Pomorski, Rabka, Szczawnica and Romanów. The dynamic development of the phenomenon awaked the need of the regulation of the legal situation of health treatment and usage of natural resources existing in the spa resorts. In the January of 1877 the Commission of the Balneology, Climatology and National Hydrology was established. Its main task was to prepare a legal act regulating the functioning of the spa resorts in Galicia. The document was enacted in 1891 (Małecka \& Marcinkowski, 2007). 
The turn of the 19th and 20th centuries is a period of the constant growth of interest in spa treatments among the clients. The process was stopped by WWI, which caused the devastation of many Polish spa resorts. The new political situation in Poland brought a new situation for the spa activity. A new legal act regulating the spa treatments and creation of the health establishments was issued in 1922. Up to 1939, seventeen new sanatoriums in Krynica, Inowrocław and Iwonicz was established. Its total capacity was approx. 2,000 places. WWII stopped again the development of the spa resorts. The situation after 1945, due to the political changes, was completely different. One of the most important consequences was a change in the spa potential of the country. Poland lost four important spa resorts situated in the eastern part, incorporated into the Soviet Union. These included, for example, popular spas such as Truskawiec (now Ukraine) and Druskienniki (now Lithuania). The situation on the western border was considerably better. The changes of the borders caused that 21 news spa resorts in the western and northern part of the country like Polanica Spa, Kudowa Spa or Świnoujście became part of Poland. Then the supervision of the spa health treatment was taken over by the Ministry of Health and the Social Security of the Polish Peoples Republic and became part of the health care system of the country. In 1966, a new legal act on spas and spa treatments was issued and became effective until 2005 (Wyrzykowski, Marak, Sołtysik, Oparka, \& Zajączkowski, 2007).

The crucial moment for the development of the spa resorts was 1989 - the year of political and economic changes. The process of withdrawal of the state from the activity of different enterprises, including spas. The lack of the financial support from the state caused a partial or total damage. The number of places in sanatoriums were reduced, majority of units were sold and changed their function. This process of decapitalization of infrastructure together with unsatisfactory offer of health establishments caused a considerable decrease of their popularity (Płonka-Syroka \& Kaźmierczak, 2012).

The reform started in the last decade of the 20th century and the Program of the Common Privatization facilitated the implementation of multiple changes in the organization of system of spa therapeutics. Many enterprises were privatized and became the property of the State Treasury subjected to the Ministry of Treasury. Although the state owned the main share of spa potential (approx. $48 \%$ of the spa places in spa centers), approx. $20 \%$ belonged to the unions and $10 \%$ to various Ministries. Just $2 \%$ of the total spa capacity of Poland was a property of the private business. On July 28, 2005, after 10 years, a new legal act on the spa therapies, spa resorts and the spa counties was issued (Małecka \& Marcinowski, 2007).

\section{Spa Tourism in Poland - definition of the phenomenon}

Spa tourism in Poland has its long tradition. This form of tourism is usually defined as the travel for the curation, rehabilitation and spa treatments linked with the specific treatments prescribed by a doctor (Januszewska, 2004). Hadzik (2007) agrees with Dryglas (2006) that spa tourism consists of three main elements: 
- Cure/treatment: treated as the most important pillar of the spa tourism;

- Leisure;

- Prevention.

Health tourism is a wider concept that embraces the curative tourism present in the spa regions since the very beginning and a newer phenomenon, defined by Mika and Pawlusiński (2007) as a "new" health tourism based on the philosophy of well-being. It refers to the desire for the improvement of person's physical and psychical state of health. Here the emotional order, biological regeneration, the personal beauty, or physical condition are stressed (Łęcka, 2003). This new version of health tourism evolves towards such forms like curative stays, the visits aimed at esthetic regeneration and the visits for the rejuvenation of the vital forces. Despite the actual form of the spa tourism, the phenomenon is always present in the spa resorts where the spa services are offered.

\section{Definition of the spa resort by the Polish law}

According to the legal act mentioned above (Notice 2012/651), a spa resort is an area where a spa therapy is offered. The area is assigned for the proper usage and the protection of the natural therapeutic resources.

A town is recognized as a spa resort if the applicant community prepares the spa report. It serves as a base for the Ministry of Health to assign the community the required title. According to the 2005 act, the spa communities should have:

- Local climate of the curative qualities,

- Unique, natural spa resources,

- Health care facility that serves the spa treatments offered by highly qualified medical staff,

- Hospitals and sanatoriums with the supporting infrastructure of a high standard,

- The devices focused on the use of the spa natural resources,

- Fulfilled legal requirements of the environment protection,

- An adequate area where the zones of the spa protection could be indicated,

- Full technical infrastructure,

- Trans-regional importance.

In a similar way, the spa resort is defined by the Polish Standardization Committee. According to its proposal, the spa resort is an area with the natural curative resources, with the access to the sea waters and the climate of the healing characteristics (or it must have at least one of the elements) and the sanatoriums and devices focused on the spa therapies. It has to be accompanied by the favorable environmental and sanitary conditions, allowing at the same time a medical treatment of specified diseases, and leisure and tourist activities. The recognition of town as a spa resort is followed by the regulation described in the legal act (Szromek, 2007). 


\section{Approaches to the research issue}

The aim of this paper is to present the situation of the spa centers in Poland in the geographical and tourist context. The spa tourism development in Poland generates many scientific questions and problems to be solved. The most important can be grouped in the research areas mentioned below:

1. Directions of the spa tourism development in Poland. Strategy of the development of spa region should be based on the three main rules: an integrated approach, partnership and the concentration on the chosen matters (Hadzik, 2007). The most important trends in the spa resort and region should be health and wellness tourism, relaxing tourism linked with qualified one, cultural tourism with the special emphasis on the urban aspect, business and congress tourism, different forms of tourism developed in the rural areas such as agro- or ecotourism and ecological tourism (Łopaciński, 2003).

2. Quality in the spa tourism, or the quality of different kinds of tourism offered in the spa regions: quality oriented towards the clients (what they expect from the spa region and its resources); quality oriented towards the production (the standardization of the spa products and the process of their preparation) and towards the spa product - defined by some unique characteristics that distinguish it from other goods offered to the clients; quality oriented towards value (Ponikowska, 2009).

3. Spa \& wellness concept in Polish spas. The main question is what kind of conditions should be accomplished. Apart from the medical ones, such as the required license issued by the state or local authority, implementation of new therapies and services or the prophylactic packages how to adjust the new spa products to the needs of the population (population that undergoes quite dynamic changes in the last decades; the population conscious of its needs, searching for the harmony of the body and spirit but having limited time for treatment). What could be a solution to this problem? A quest for a new product or a new philosophy of use of the spa resources, techniques and devices leads to the new paradigm in the functioning of spa resorts (Dąbrowska-Zielińska \& Wołk-Musiał, 2012; Mika \& Pawlusiński, 2007, Rapacz \& Jaremen, 2013).

4. Social determinants of the spa tourism development. It is a quite broad category that may include different elements. One of them is the motivation of the tourist migration. The description of the human expectations towards the tourist travel is crucial for the preparation of a better product - a proper answer to the tourist's needs. Another factor that determines the spa tourism development is demography. The growing number of the third age people group favors the spa tourism, which helps solve the problems in this group: an increase in the demand for the services related to the care about health in both ways: curative and prophylactic (Karbowiak, 2015). Next factor that accompanies the previous one is free time and its distribution. In the developed world where the process of production is highly automated, the "resources" of time excluded from the work are quite considerable. In order to use it for the regular 
spa treatment, the regular health resort visitor needs around three weeks for his/ her stay, which is quite easy in "the silver heads" could be also "third age tourists" segment of the tourist market and much more difficult for the working people. Although the annual leave lasts up to one month, it is rarely used for just one holiday. The tendency is to participate in two or even three shorter tourist trips per year. The spa resorts react with an offer of shorter wellness stays using a natural resources potential (Toczek-Werner \& Soltysik, 2007). At present, an influential factor is the industrialization process that causes serious changes in the way of life of major part of the world population. One of them is the fast pace of life resulting in permanent stress and the detriment of health. Spa tourism in this perspective appears as a useful tool for healing this kind of problems. The fashion factor also seems quite important. The present society follows trends - and one of the most important is a healthy way of living stressing the proper nutrition and care about the physical condition. Thus, the spa and wellness treatments are well accepted by the majority and very often a spa stay is part of the image desired in some groups of the society (Szymańczyk \& Wróbel, 2007).

5. Perspectives of the spa tourism development facing new economic and political situation. Although the change in Poland took place in 1989, its consequences last for decades. One of the most important elements is the commercialization of the spa potential and spa services. Investigation of this period in Polish literature concerns:

- Place of spa tourism in the structure of tourist market,

- Privatization process facing the need of the maintenance of the high level of services,

- Competitiveness of spa services and offer at the regional level and on European markets,

- Legal aspects of the spa functioning for different target groups,

- Cooperation between different institutions for the development of spa tourism,

- Innovation of the services and their promotion,

- The role of the state and local authorities in the organization of the spa resorts (Wyrzykowski, Marak, Sołtysik, Oparka, \& Zajączkowski, 2007).

6. Quality of the environment and the development of the spa resorts. The dynamic development of tourism in spa and its mass character may cause the worsening of the natural resources that spas have at their disposal. The resources like springs or climate can easily be spoiled by in-proper behavior and the decisions of the existing subjects. The most common result of the uncontrolled activity may be water and air pollution - the crucial factors for the spa existence and success on the tourist market. The quality of environment is accompanied by the concept of sustainable tourism development. The proper use of the natural values of the local (resources) and the regional (landscape) scale is a key to success. This should be linked with the legal environment created for the investors. The other part of the sustainability phenomenon - the society - is also quite important. The well-educated local community is the first 
group defending the natural and cultural values of the spa region and the best way to conserve them for the future generations (Lewandowska, 2007).

7. Tourist attractiveness of the spa regions. All Polish spa resorts are situated in an attractive environment - both cultural and natural one. Such an accumulation of different values makes a spa region exceptionally important for tourism in its many different forms: cultural, active, adventure, rural or qualified. The proper use of these values for the spa purposes and their influence on the spa tourism development should be crucial for the scientific investigation (Widawski, 2007; Wyrzykowska, 2007).

In order to achieve the exact picture of the spa tourism development in the geographical context, first, the division of the spa resorts in the country is presented. Different approaches organize the spas concerning their natural and curative resources together with the kind of landscape. Furthermore, the legal situation of the spa centers is presented. The Polish law strictly lay down the economy activity that can be undertaken depending on the proximity of the resources that are used for the medical treatment.

One of the most important part of the paper is to present the main characteristics of the Polish spas. All 45 resorts were described according to their geographical localization or the year of their establishment. In a more detailed way, the medical treatments that can be found on their offer, were presented emphasizing their spatial distribution.

The final part, significant for this paper, describes the situation of the spa resorts in the tourist context. The importance of spa tourism in Poland is presented through the analysis of the statistical data that refers to the accommodation units in the spas, health tourist establishments and their use and tourists' characteristics. All the data was elaborated for the year 2015 and was retrieved from the Central Statistical Office of Poland.

\section{Results}

\section{Divisions of the spa resorts in Poland}

The main category used for the division of the spa resorts is its geographical location and landform recognized both by Polish popular law (a literature dedicated to law) and scientific literature. It has a considerable influence on the existence of the mineral resources, climate, groundwater, flora and fauna of the area. Its localization shapes the character and the attractiveness of the spa resort and also its tourist use. Taking into account this element, the spas in Poland are divided as follows:

- Lowland spas - situated up to $200 \mathrm{~m}$ asl (16 spas);

- Foothill spas - situated from 200 to $400 \mathrm{~m}$ asl (14 spas);

- Mountainous spas - situated between 400 and $800 \mathrm{~m}$ asl (8 spas);

- Seaside spas - situated in the distance up to $3 \mathrm{~km}$ from the sea shore (6 spas).

The Polish norm introduces its own categorization and the main element of the division is the location above sea level. According to the legal act quoted above, there are 
lowland spas, foothill spas, mountain spas. In this case, the only difference is the limit - 700 instead of $800 \mathrm{~m}$ asl. Each seaside spa is included into the first group and the last group embraces the Alpine spas - the resorts situated higher than $700 \mathrm{~m}$ asl. It has to be mentioned that in the case of Poland the last group is empty (Kraś, 2011; Karbowiak, 2015).

Another category of the spa division in the country is the kind of natural resources they have at their disposal. According to this factor, Ministry of Health divides the spas into:

- Springs - all the spas with mineral waters,

- Mud spas -spas where the treatment is based on the mud use,

- Mixed spas - all the spas having at their disposal both kinds of resources: mineral waters and muds.

A slightly different division based on natural resources is offered by the Polish Norm (PN-Z-11000:2001). According to the kinds of resources, the spas in Poland are divided into:

- Springs - the spas where curation is based on mineral waters,

- Mud spas - the spas where mud is used for the treatments,

- Climate spas - the spas where healing character of climate is used for the medical purposes,

- Seaside spas - the spas where the treatment is based on the use of specific sea climate together with the sea waters,

- Subterranean spas - where for the therapeutic purposes, treatments use the microclimate of the underground excavations.

In Poland, the most popular type of spa (especially in the southern part of the country) are the springs where the basic source of treatments are the mineral waters. The mud spas are mainly located in the north of Poland. The examples of the mixed spas are Krasnobród and Augustów - climate-mud spas and Nałęczów - climate spring spas.

As for the spatial distribution of spas in Poland, it can be stated that almost $50 \%$ of the total number of spas (22) are situated in the southern part of the country, particularly in Dolnoślaskie Voivodship (11 spas mainly in the Sudety Mountain range). The second place is taken by Małopolskie Voivodship. Its 9 spas are mainly in the Carpathian Mountain range. Three spas situated in the same region administratively belong to the Podkarpackie region. In Sląskie Voivodship there is just one spa.

The lowland spas are more dispersed in comparison with the mountainous ones. All of the twenty-two spas are distributed in 13 different voivodships. At the Polish seaside, there are 6 different spas and another 15 are situated in 11 different administrative regions. $51.2 \%$ of the total number of the certified spas are in the mountains and $48.8 \%$ are in the lowland areas. Most of the spas are parts of towns, usually small ones (32 out of 45). Within the big agglomerations (Warsaw, Gdańsk-Gdynia-Sopot and Cracow), 


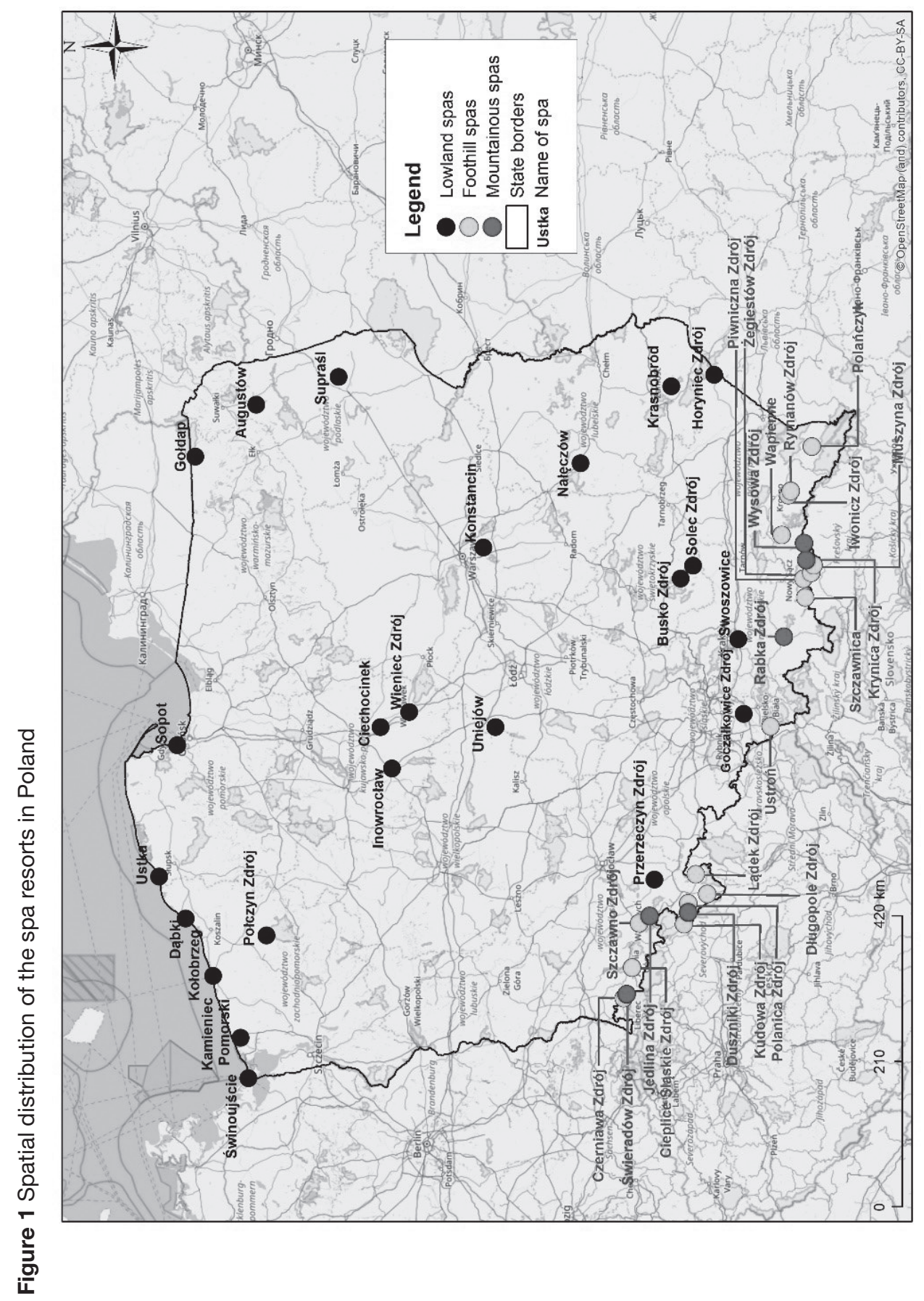

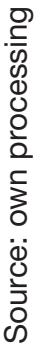


there are three spas: Konstancin-Jeziorna, Sopot and Swoszowice.

The last division, offered in Polish literature, considers the localization of the spa as referred to the neighboring areas. They can be divided into:

- Solidarity spas - the spas situated alone in various areas such as tourist or agriculture ones,

- A group of spas - concentration of different health centers.

Solidarity spas can be further divided:

- The single system - in such a system the spa is a dominant cure center inn a bigger area. Polańczyk, Horyniec, Wapienne, Wysowa or Połczyn Zdrój are examples of this system;

- Spa-leisure agglomeration - these are the spas which are accompanied by relaxation or ski resorts. Such a localization is usually advantageous unless the tourism movement negatively influences the functioning of the spa system.

It is worth mentioning that the localization of the spa near the centers of a similar function is positive for the clients with the therapeutic offer (Kalda \& Lalicka, 2014).

\section{Spatial organization of the spas in Poland}

In Poland, the spa resort has to have its spatial characteristics. According to the legal act of 2005, in the spa resort, different spa protection areas are defined; they are called zone "A", "B" and " $\mathrm{C}$ ".

Zone "A" is a part of the spa area where the share of the green areas occupies at least $65 \%$ of its surface. In this area, the spa treatment or tourist facilities are situated. Such objects cannot impede the healing process. These facilities are, for example, pension houses, restaurants or pubs.

In zone "B" the green areas should cover at least $50 \%$ of surface. This area adheres to zone "A" and the human activity can be led there unless it destroys the environment. These tourist facilities are, for instance, an accommodation offer, recreational and sport objects and residential buildings.

The " $\mathrm{C}$ " zone is the one where the green areas are not smaller than $45 \%$ and it adheres to zone "B". The main purpose of its creation is the protection of the landscape and climate values together with the natural spa resources.

The detailed ordinance concerning the activity in the zones defined by the act is forbidden or considerably reduced in the zone " $\mathrm{A}$ " (building industrial plants, single-family houses or residential buildings, free-standing garages, trade structures of the surface bigger than $400 \mathrm{~m}^{2}$, petrol stations or the points of the fuel distribution, highways or express roads, parking places crossing the established limits, other buildings that can considerably affect the environment, especially auto service stations, smokehouses, tan- 
neries, with the exception for the objects that serve the improvement of the sanitary conditions of the spa like a sewage system, gas network, gas boiler rooms, river dams or hydroelectric or wind power plant). It is also forbidden to launch the tent or campsites, construct the tourist or camp cottages, open the bazaars (except for handicraft souvenirs or regional products' stands). The following activities are also prohibited: the organization of mass events that may impede the treatment process or the spa rehabilitation and the entertaining activities that could disturb the curfew between 22.00 and 6.00 with the exception for the mass events planned by the local authority. As for the natural resources, only the curative ones can be quarried. Cutting trees or any activity that could spoil the landscape, urban character of spa resort or the healing climate are forbidden.

The 2005 act is less restrictive concerning different investments and activities that can be practiced in zone "B". Some structures are forbidden in this area like the construction of the petrol stations situated closer than $500 \mathrm{~m}$ from the zone "A" border, parking places of the capacity more than 50 places (underground parking is allowed), the industry plants construction as well as the trade centers of the surface more than $400 \mathrm{~m}^{2}$ or any other activity that could spoil the natural resources of the spa resort like climate, springs or muds.

In zone „C" the restrictions are fewer. It is not allowed to build the industrial plants, to excavate different mineral resources than the curative ones or to cut the trees for timber (Act 2005/167/1399).

\section{Characteristic of the spa resorts in Poland}

In Poland, 45 spa resorts are certified. They can be characterized by many features, e.g. localization - the administrative region they belong to, the geography - kind of the landscape accompanying them, the year their got its official status and the number and type of treatments they offer.

Most of the spas - 17 - are situated in the lowland regions (see Figure 1 and Table 1). The second place is taken up by the foothill spas - these are 14. Another 8 spas are in the mountainous areas and last 6 are within the distance of no more than $3 \mathrm{~km}$ form the sea shore. Concerning the administrative division of Poland, the most spas are situated in Dolnośląskie voivodship with 11 spa resorts, which is $25 \%$ of the total spa potential of the country. Next region with 9 spas is Małopolskie. The third position is occupied by Zachodniopomorskie with 5 resorts. Most of the spas (36) obtained their status in 1967 when the first legal act on the functioning of the health care system after the WWII in Poland was issued. Other spas were established after the political and economic changes of 1989. The first one was Augustów - nominated in 1993 and the latest one is Uniejów (the only spa in lódzkie region), created in 2012.

Together with the official spas presented in the table above, there is also a spa sanatorium established in the underground excavation. It is one of the most popular tourist destination of małopolskie region - a former salt mine in Wieliczka, in 1978 it was inscribed into the UNESCO heritage list. 
Table 1 Spas in Poland

\begin{tabular}{|c|c|c|c|c|}
\hline Locality & Voivodship & Spa type & $\begin{array}{c}\text { Year of } \\
\text { establishment }\end{array}$ & $\begin{array}{l}\text { Number of } \\
\text { treatments }\end{array}$ \\
\hline Augustów & Podlaskie & Lowland & 1993 & 4 \\
\hline Busko-Zdrój & Świętokrzyskie & Lowland & 1967 & 6 \\
\hline Ciechocinek & Kujawsko-pomorskie & Lowland & 1967 & 10 \\
\hline Cieplice-Zdrój & Dolnośląskie & Foothill & 1967 & 6 \\
\hline Czerniawa-Zdrój & Dolnośląskie & Foothill & 1967 & 7 \\
\hline Dąbki & Zachodniopomorskie & Seaside & 2007 & 6 \\
\hline Długopole-Zdrój & Dolnośląskie & Foothill & 1967 & 6 \\
\hline Duszniki-Zdrój & Dolnośląskie & Foothill & 1967 & 8 \\
\hline Goczałkowice-Zdrój & Śląskie & Lowland & 1967 & 4 \\
\hline Gołdap & Warmińsko-mazurskie & Lowland & 2000 & 4 \\
\hline Horyniec-Zdrój & Podkarpackie & Lowland & 1967 & 6 \\
\hline Inowrocław & Kujawsko-pomorskie & Lowland & 1967 & 5 \\
\hline Iwonicz-Zdrój & Podkarpackie & Foothill & 1967 & 8 \\
\hline Jedlina-Zdrój & Dolnośląskie & Mountainous & 1967 & 7 \\
\hline Kamień Pomorski & Zachodniopomorskie & Seaside & 1967 & 5 \\
\hline Kołobrzeg & Zachodniopomorskie & Seaside & 1967 & 11 \\
\hline Konstancin-Jeziorna & Mazowieckie & Lowland & 1967 & 3 \\
\hline Krasnobród & Lubelskie & Lowland & 2002 & 6 \\
\hline Krynica-Zdrój & Małopolskie & Mountainous & 1967 & 8 \\
\hline Kudowa-Zdrój & Dolnośląskie & Foothill & 1967 & 7 \\
\hline Lądek-Zdrój & Dolnośląskie & Mountainous & 1967 & 7 \\
\hline Muszyna & Małopolskie & Foothill & 1967 & 4 \\
\hline Nałęczów & Lubelskie & Lowland & 1967 & 1 \\
\hline Piwniczna-Zdrój & Małopolskie & Foothill & 1967 & 4 \\
\hline Polanica-Zdrój & Dolnośląskie & Foothill & 1967 & 5 \\
\hline Polańczyk & Podkarpackie & Foothill & 1999 & 6 \\
\hline Połczyn-Zdrój & Zachodniopomorskie & Lowland & 1967 & 6 \\
\hline Przerzeczyn-Zdrój & Dolnośląskie & Lowland & 1997 & 4 \\
\hline Rabka-Zdrój & Małopolskie & Mountainous & 1967 & 6 \\
\hline Rymanów-Zdrój & Podkarpackie & Foothill & 1967 & 5 \\
\hline Solec-Zdrój & Świętokrzyskie & Lowland & 1967 & 5 \\
\hline Sopot & Pomorskie & Seaside & 1999 & 5 \\
\hline Supraśl & Podlaskie & Lowland & 2002 & 5 \\
\hline
\end{tabular}




\begin{tabular}{|l|l|c|c|c|}
\hline \multicolumn{1}{|c|}{ Locality } & \multicolumn{1}{|c|}{ Voivodship } & Spa type & $\begin{array}{c}\text { Year of } \\
\text { establishment }\end{array}$ & $\begin{array}{c}\text { Number of } \\
\text { treatments }\end{array}$ \\
\hline Swoszowice & Małopolskie & Lowland & 1967 & 5 \\
\hline Szczawnica & Małopolskie & Mountainous & 1967 & 5 \\
\hline Szczawno-Zdrój & Dolnośląskie & Foothill & 1967 & 9 \\
\hline Świeradów-Zdrój & Dolnośląskie & Mountainous & 1967 & 11 \\
\hline Świnoujście & Zachodniopomorskie & Seaside & 1967 & 10 \\
\hline Uniejów & Łódzkie & Lowland & 2012 & 5 \\
\hline Ustka & Pomorskie & Seaside & 1988 & 7 \\
\hline Ustroń & Śląskie & Foothill & 1967 & 10 \\
\hline Wapienne & Małopolskie & Foothill & 1967 & 2 \\
\hline Wieniec-Zdrój & Kujawsko-pomorskie & Lowland & 1967 & 6 \\
\hline Wysowa & Małopolskie & Mountainous & 1967 & 10 \\
\hline Żegiestów-Zdrój & Małopolskie & Mountainous & 1967 & 3 \\
\hline
\end{tabular}

Source: own processing based on Ministry of Health (2017)

In the Polish spas - according to the legal act issued in 2005 - seventeen different medical treatments are offered: orthopedic-traumatic diseases (1), the nervous system diseases (2), rheumatological diseases (3), Cardiac diseases and hypertension (4), peripheral vessels diseases (5), upper respiratory tract diseases (6), lower respiratory tract diseases (7), digestion system diseases (8), diabetes (9), obesity (10), endocrine diseases (11), osteoporosis (12), skin diseases (13), female illness (14), kidney and urinary tract diseases (15), blood and hematopoietic system diseases (16), eye diseases (17) (see: tab 2). The table below shows the distribution of the medical treatments in the spa resorts in Poland.

The medical treatments offer of the Polish spas is wide. Six treatments are offered in more than half of the spas. The most common is the rheumatological diseases treatment present in 41 spas and the orthopedic-traumatic diseases treatment offered in 39 spas. The least popular is eye diseases treatment (17) that is offered only in Cieplice Slackie Spa. Just slightly more popular is the blood and hematopoietic system diseases treatment offered by Długopole, Krynica and Kudowa Spas.

The best equipped in different kind of treatment profiles are two spas: Świeradów Spa and Kołobrzeg with 11 different profiles offered. Next four spas: Wysowa, Ustron, Świnoujście and Ciechocinek provide 10 different kinds of treatments using their natural resources.

The medical treatments presented above are served in the health establishment - an establishment providing health care services located in the area of a health resort and using its natural resources when providing health care services and providing accommodation services. The spa infrastructure in Poland is divided into: spa hospitals, spa sanatoriums, spa sanatoriums and hospitals for children, the physiological establishments, sanatorium in the underground mining excavation and spa outpatient clinic. 
Table 2 Distribution of the medical treatments in the spa resorts in Poland

\begin{tabular}{|c|c|c|c|c|c|c|c|c|c|c|c|c|c|c|c|c|c|}
\hline $\begin{array}{l}\text { Locality/ } \\
\text { kind of treatment }\end{array}$ & 1 & 2 & 3 & 4 & 5 & 6 & 7 & 8 & 9 & 10 & 11 & 12 & 13 & 14 & 15 & 16 & 17 \\
\hline Augustów & $\mathbf{x}$ & & $\mathbf{x}$ & & $\mathbf{x}$ & & & & & & & $x$ & & & & & \\
\hline Busko-Zdrój & $\mathbf{x}$ & $\mathbf{x}$ & $\mathbf{x}$ & $\mathbf{x}$ & & & & & & & & $\mathbf{x}$ & $x$ & & & & \\
\hline Ciechocinek & $\mathbf{x}$ & $\mathbf{x}$ & $\mathbf{x}$ & $\mathbf{x}$ & $\mathbf{x}$ & $\mathbf{x}$ & & & $\mathbf{x}$ & $\mathbf{x}$ & & $\mathbf{x}$ & & $\mathbf{x}$ & & & \\
\hline Cieplice-Zdrój & $\mathbf{x}$ & $\mathbf{x}$ & $\mathbf{x}$ & & & & & & & & & $\mathbf{x}$ & & & $\mathbf{x}$ & & $\mathbf{x}$ \\
\hline Czerniawa-Zdrój & $\mathbf{x}$ & & $\mathbf{x}$ & $\mathbf{x}$ & & $x$ & $\mathbf{x}$ & & $\mathbf{x}$ & & & $\mathbf{x}$ & & & & & \\
\hline Dąbki & $\mathbf{x}$ & & $\mathbf{x}$ & $\mathbf{x}$ & & $\mathbf{x}$ & $\mathbf{x}$ & & & & $\mathbf{x}$ & & & & & & \\
\hline Długopole-Zdrój & $\mathbf{x}$ & & $\mathbf{x}$ & & $\mathbf{x}$ & & & $\mathbf{X}$ & $\mathbf{x}$ & & & & & & & $\mathbf{x}$ & \\
\hline Duszniki-Zdrój & $\mathbf{x}$ & & $\mathbf{x}$ & $\mathbf{x}$ & $x$ & & $\mathbf{x}$ & $\mathbf{X}$ & & & & $\mathbf{x}$ & & $\mathbf{x}$ & & & \\
\hline Goczałkowice-Zdrój & $\mathbf{x}$ & $\mathbf{x}$ & $\mathbf{x}$ & & & & & & & & & $x$ & & & & & \\
\hline Gołdap & $\mathbf{x}$ & & $\mathbf{x}$ & & & & $\mathbf{x}$ & & & & & & & $\mathbf{x}$ & & & \\
\hline Horyniec-Zdrój & $\mathbf{x}$ & $\mathbf{x}$ & $\mathbf{x}$ & & & & & & & & & $\mathbf{x}$ & $\mathbf{x}$ & $\mathbf{x}$ & & & \\
\hline Inowrocław & $\mathbf{x}$ & $\mathbf{x}$ & $\mathbf{x}$ & $\mathbf{x}$ & $x$ & & & $\mathbf{X}$ & & & & & & & & & \\
\hline Iwonicz-Zdrój & $\mathbf{x}$ & $\mathbf{x}$ & $\mathbf{x}$ & & & $x$ & & $\mathbf{x}$ & & $\mathbf{x}$ & & $\mathbf{x}$ & $\mathbf{x}$ & $\mathbf{x}$ & & & \\
\hline Jedlina-Zdrój & $\mathbf{x}$ & & $\mathbf{x}$ & $\mathbf{x}$ & & $\mathbf{x}$ & $\mathbf{x}$ & $\mathbf{x}$ & & & & & & & $\mathbf{x}$ & & \\
\hline Kamień Pomorski & $\mathbf{x}$ & $\mathbf{x}$ & $\mathbf{x}$ & $\mathbf{x}$ & & & $\mathbf{x}$ & & & & & & & & & & \\
\hline Kołobrzeg & $\mathbf{x}$ & $\mathbf{x}$ & $\mathbf{x}$ & $x$ & & $x$ & $\mathbf{x}$ & & $\mathbf{x}$ & $x$ & $\mathbf{x}$ & $\mathbf{x}$ & $\mathbf{x}$ & & & & \\
\hline Konstancin-Jeziorna & & $\mathbf{x}$ & & $\mathbf{x}$ & & $x$ & & & & & & & & & & & \\
\hline Krasnobród & $\mathbf{x}$ & $\mathbf{x}$ & & $\mathbf{x}$ & & $x$ & $x$ & & & $x$ & & & & & & & \\
\hline Krynica-Zdrój & & $\mathbf{x}$ & $\mathbf{x}$ & & & $\mathbf{x}$ & & $\mathbf{X}$ & $\mathbf{x}$ & & & & & $\mathbf{x}$ & $\mathbf{x}$ & $\mathbf{x}$ & \\
\hline Kudowa-Zdrój & $x$ & & $x$ & $x$ & $x$ & & & $\mathbf{X}$ & & & $x$ & & & & & $x$ & \\
\hline Lądek-Zdrój & $\mathbf{x}$ & $\mathbf{x}$ & $\mathbf{x}$ & $\mathbf{x}$ & & & & & & & & $x$ & $x$ & $x$ & & & \\
\hline Muszyna & & & $x$ & & & $x$ & & $x$ & & & $\mathbf{x}$ & & & & & & \\
\hline Nałęczów & & & & $\mathbf{x}$ & & & & & & & & & & & & & \\
\hline Piwniczna-Zdrój & & & $\mathbf{x}$ & & & $x$ & $x$ & $\mathbf{X}$ & & & & & & & & & \\
\hline Polanica-Zdrój & $x$ & & $\mathbf{x}$ & $x$ & & $x$ & & $x$ & & & & & & & & & \\
\hline Polańczyk & $\mathbf{x}$ & & $\mathbf{x}$ & $\mathbf{x}$ & & $\mathbf{x}$ & & & $x$ & & $x$ & & & & & & \\
\hline Połczyn-Zdrój & $x$ & $\mathbf{x}$ & $\mathbf{x}$ & & & & & & & $x$ & & $\mathbf{x}$ & & $\mathbf{x}$ & & & \\
\hline Przerzeczyn-Zdrój & $\mathbf{x}$ & $\mathbf{x}$ & $\mathbf{x}$ & & & & & & & & & & & & & & \\
\hline Rabka-Zdrój & $\mathbf{x}$ & & & $\mathbf{x}$ & & $x$ & $x$ & & $x$ & & & & $x$ & & & & \\
\hline Rymanów-Zdrój & $\mathbf{x}$ & & $\mathbf{x}$ & $\mathbf{x}$ & & $x$ & $x$ & & & & & & & & $\mathbf{x}$ & & \\
\hline Solec-Zdrój & $x$ & $x$ & $\mathbf{x}$ & & & & & & & & & $x$ & $x$ & & & & \\
\hline Sopot & $x$ & $x$ & $x$ & $x$ & & & $x$ & & & & & $x$ & & & & & \\
\hline Supraśl & $x$ & & $x$ & $x$ & & $x$ & $x$ & & & & & & & & & & \\
\hline Swoszowice & $\mathbf{x}$ & $\mathbf{x}$ & $\mathbf{x}$ & & & & & & & & & $\mathbf{x}$ & $x$ & & & & \\
\hline Szczawnica & $\mathbf{x}$ & & $\mathbf{x}$ & & & $\mathbf{x}$ & $x$ & & & $\mathbf{x}$ & & & & & & & \\
\hline
\end{tabular}




\begin{tabular}{|l|c|c|c|c|c|c|c|c|c|c|c|c|c|c|c|c|c|}
\hline $\begin{array}{l}\text { Locality/ } \\
\text { kind of treatment }\end{array}$ & $\mathbf{1}$ & 2 & 3 & 4 & 5 & 6 & 7 & 8 & 9 & 10 & 11 & 12 & 13 & 14 & 15 & 16 & 17 \\
\hline Szczawno-Zdrój & $\mathbf{x}$ & & $\mathbf{x}$ & & & $\mathbf{x}$ & $\mathbf{x}$ & $\mathbf{x}$ & $\mathbf{x}$ & $\mathbf{x}$ & & $\mathbf{x}$ & & & $\mathbf{x}$ & & \\
\hline Świeradów-Zdrój & $\mathbf{x}$ & $\mathbf{x}$ & $\mathbf{x}$ & $\mathbf{x}$ & $\mathbf{x}$ & $\mathbf{x}$ & $\mathbf{x}$ & & $\mathbf{x}$ & & & $\mathbf{x}$ & $\mathbf{x}$ & $\mathbf{x}$ & & & \\
\hline Świnoujście & $\mathbf{x}$ & $\mathbf{x}$ & $\mathbf{x}$ & $\mathbf{x}$ & & $\mathbf{x}$ & $\mathbf{x}$ & & & $\mathbf{x}$ & $\mathbf{x}$ & $\mathbf{x}$ & $\mathbf{x}$ & & & & \\
\hline Uniejów & $\mathbf{x}$ & $\mathbf{x}$ & $\mathbf{x}$ & & $\mathbf{x}$ & & & & & & & & $\mathbf{x}$ & & & & \\
\hline Ustka & $\mathbf{x}$ & $\mathbf{x}$ & $\mathbf{x}$ & $\mathbf{x}$ & & $\mathbf{x}$ & $\mathbf{x}$ & & & & $\mathbf{x}$ & & & & & & \\
\hline Ustroń & $\mathbf{x}$ & $\mathbf{x}$ & $\mathbf{x}$ & $\mathbf{x}$ & $\mathbf{x}$ & $\mathbf{x}$ & $\mathbf{x}$ & & $\mathbf{x}$ & $\mathbf{x}$ & & $\mathbf{x}$ & & & & & \\
\hline Wapienne & $\mathbf{x}$ & & $\mathbf{x}$ & & & & & & & & & & & & & & \\
\hline Wieniec-Zdrój & $\mathbf{x}$ & $\mathbf{x}$ & $\mathbf{x}$ & $\mathbf{x}$ & & $\mathbf{x}$ & & & & & & $\mathbf{x}$ & & & & & \\
\hline Wysowa & $\mathbf{x}$ & $\mathbf{x}$ & $\mathbf{x}$ & & & $\mathbf{x}$ & $\mathbf{x}$ & $\mathbf{x}$ & $\mathbf{x}$ & $\mathbf{x}$ & & $\mathbf{x}$ & & & $\mathbf{x}$ & & \\
\hline Żegiestów-Zdrój & & & $\mathbf{x}$ & & & & & $\mathbf{x}$ & & & & & & & $\mathbf{x}$ & & \\
\hline
\end{tabular}

Source: own processing based on Ministry of Health (2017)

In the spa hospital, spa sanatoriums and the same objects focused on children, each patient is offered a 24-hours stationary health service supervised by the doctor supported by nurse, the specified treatment program and the use of the natural resources and the spa treatment devices and, finally, the health education (Jagusiewicz, 2002).

The spa treatments are supported by the spa devices like: drinking rooms in the spring spa, graduation towers, parks, recreational paths, medicinal and rehabilitation spa swimming pools or underground mining excavation prepared for the spa activity.

Although the most important elements for the spa functioning are the natural resources together with the health infrastructure, it is worth stressing the importance of the tourist values: cultural and natural ones. Its importance for the spa tourism increases and its presence often decides about the selection of the spa resort (Widawski, 2007).

\section{Spatial distribution of the spa accommodation units in Poland}

The three most visited counties in Poland are: Warszawa (5 161200 overnight stays), Kraków (4 573900 overnight stays) and Kołobrzeski county - zachodniopomorskie voivodship - (4 303800 overnight stays). The analysis of the top 20 visited counties shows the following trends:

- Top 20 of the most often visited counties gives more than a half of overnight stays in the country $(52.8 \%)$;

The top 20 counties are the seaside ones (including spa counties like: kołobrzeski, kamieński county and Świnoujście - zachodniopomorskie voivodship), mountainous (like jeleniogórski and kłodzki county with its 5 spa resorts - dolnośląskie voivodship). The lowland area is represented by aleksandrowski county with Ciechocinek spa - kujawsko-pomorskie voivodship that groups the major number of tourists visiting the region. 
If the analysis considered the situation in the 76 most visited counties in Poland $(80.9 \%$ of the total number of overnight stays), the importance of the spa resorts would become even clearer. In this group, the highest index of beds utilization is the following counties: aleksandrowski (kujawsko-pomorskie voivodship) (73.6\%), inowrocławski (kujawsko-pomorskie voivodship) (69.9\%), buski (świętokrzyskie voivodship) (66.3\%), kołobrzeski (zachodniopomorskie voivodship) (63.9\%), lubaczowski (podkarpackie voivodship) (60.6\%), krośnieński (podkarpackie voivodship) (57\%), gołdapski (warmińsko-pazurskie voivodship) (56.4\%), Sopot (pomorskie voivodship) (56\%), Warszawa (mazowieckie voivodship) $(54.6 \%)$ and Świnoujście (zachodniopomorskie voivodship) (54.4\%).

In the 10 mentioned counties, only the capital - Warszawa - has no spa resort within its borders (GUS, Turystyka w 2015, p.87).

\section{Tourists in the spa resorts}

The analysis of the tourists in the spa resorts in Poland should begin with the research of motivation of the travelers visiting spa destinations, both national and foreign. The most important goals for the tourist visit, according to the statistics presented by the Statistics Poland (Główny Urząd Statystyczny), are recreation and holiday, visiting friends and relatives, and health motivation.

Table 3 National tourist travels of the Polish citizens older than 15 years according to their motivations (2015)

\begin{tabular}{|l|r|r|r|}
\hline Goal & Total & Short-term travels & Long-term travels \\
\hline Total & $100 \%$ & $100 \%$ & $100 \%$ \\
\hline Recreation, holiday & 38.6 & 26 & 58.1 \\
\hline VFR & 51.7 & 64.2 & 32.5 \\
\hline Health & $\mathbf{2 . 7}$ & $\mathbf{1 . 1}$ & $\mathbf{5 . 3}$ \\
\hline Religion & 1.2 & 1.6 & 0.5 \\
\hline Education & 1 & 1.2 & 0.8 \\
\hline Shopping & 0.1 & 0.2 & 0 \\
\hline Business & 3.2 & 3.9 & 2.1 \\
\hline Other & 1.4 & 1.9 & 0.7 \\
\hline
\end{tabular}

Source: Statistics Poland (2016, p. 111)

Obviously, the most important travelling motivation for the Polish citizens is to visit friends and relatives. More than half of the travelling population choses this purpose. The second most important goal is recreation and holiday and these two with the share exceeding $90 \%$ practically determine all the activities on the local tourist market. The third position is taken up by business trips and the fourth place - by health purposes (it is 
important for almost $3 \%$ of the travelling residents, which is $1,096,300$ ). The situation is slightly different if the long-term trips - typical of the health stays - are considered. The first two motivational aspects (visiting friends and relatives as well as holiday) are beyond the reach of any other motivation, however, the health motivation is the main reason for travelling for more than $5 \%(825,800$ persons $)$ of the population, which is more than for the business motivation.

In the case of the foreign tourists visiting Poland, the most important reason for travel is visiting friends and relatives. Almost 7 million of tourists from abroad indicate this goal, which is $40.5 \%$. The second most important reason for visiting Poland is business almost every fourth traveler declares this aim. Recreation and holiday as the main reason is slightly less important, with $23 \%$ share of the market. The health reasons are less important for foreigners to visit the country. Only 119, 100 tourists $(0.6 \%)$ uses local health facilities and resources to spend their holiday. In addition, one important thing should be stressed. Among many reasons for visiting the spa resorts in Poland, the spa \& wellness phenomenon has to be mentioned. The search for the well-being, the right balance between the physical and spiritual parts of human being is often assigned to the specific tourist product. It is usually based on the spa resort potential like mineral waters, muds or climate. Thus, the spa \& wellness offer is mainly in the spas. Since 1990s of the last century this kind of products has accompanied the regular health treatments and served as an important source of the income.

\section{Health tourist establishments and their use}

To judge the position of spa tourism in the tourist offer of Poland, an analysis of the health establishments within the total accommodation offer and their use is needed. The total capacity of the accommodation units of the country for 2015 is 710,274 places. The group of hotels and similar establishments share is $42.5 \%$. Other facilities offer 408, 719 beds $(57.5 \%)$. In this second category, among 16 different types, there are also the health establishments. Its share in the category is around 9\% (35, 671 beds) and in the total number of places, it is $5 \%$.

The highest number of beds - 10, 085 - is offered by zachodniopomorskie region (the spa resorts in the analysed regions - voivodships: see table $\mathrm{nr} 1$ ). As far as the number of beds is concerned, kujawsko-pomorskie (6, 053 beds) comes second, małopolskie with 5, 102 beds comes third, next is dolnoślaskie (4, 031 beds) and then podkarpackie with 3,093 beds in the health units. In the case of other voivodships, the capacity never exceeds 2,000 beds and three of them (wielkopolskie, opolskie and lubuskie) do not have a single bed to offer. If the share of the health establisments within the other facilities category by the regions is considered, the highest importance of the health units is in kujawsko-pomorskie region with the score around 35\%. Swiętokrzyskie is second with $20.4 \%$ share, then podkarpackie with $19 \%$ and dolnośląskie with $15 \%$ share.

Another indicator that could be useful for the investigation of the spa tourism situation on the Polish tourist market would be the occupancy rate. 
Figure 2 Number of beds in the health establishments by voivodships, 2015

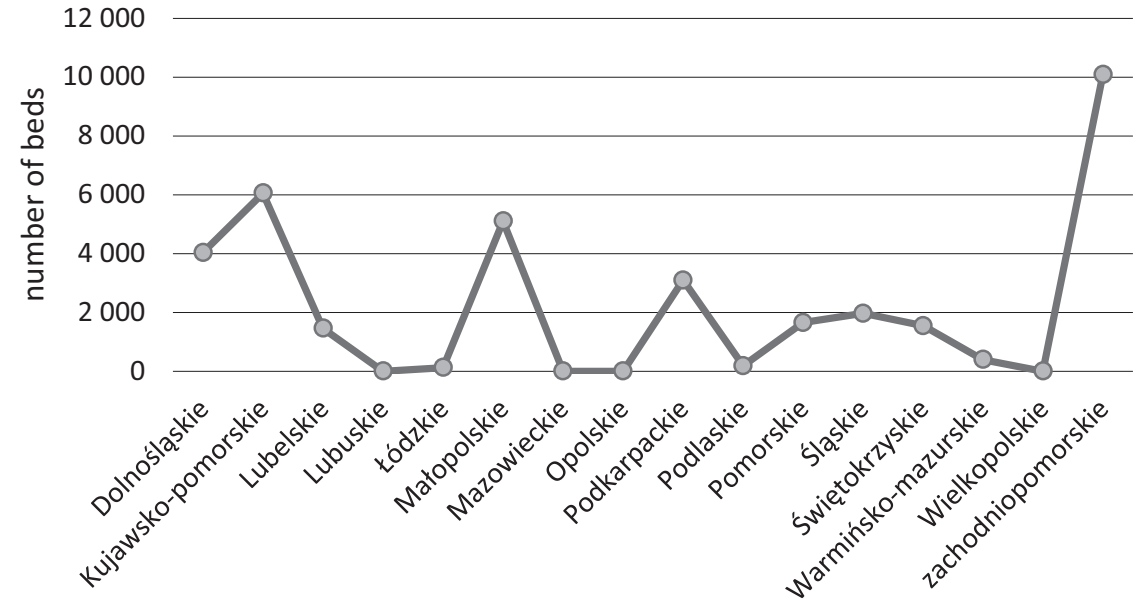

voivodship

Source: Statistics Poland (2016, p.173)

Table 4 Occupancy rate of bed places in the tourist accommodation establishments in 2015

\begin{tabular}{|l|c|}
\hline Category of the accommodation establishment & Share (in \%) \\
\hline Total & 36.7 \\
\hline Hotels and similar establishments & 36.7 \\
\hline Hotels & 39.1 \\
\hline Motels & 22.5 \\
\hline Boarding houses & 27.4 \\
\hline Other hotel facilities & 28.1 \\
\hline Other facilities & 36.7 \\
\hline Excursion hostels & 25.1 \\
\hline Shelters & 24.6 \\
\hline Youth hostels & 28.6 \\
\hline School youth hostels & 21.3 \\
\hline Holiday centers & 37.6 \\
\hline Holiday youth centers & 41.3 \\
\hline Training-recreational centers & 29.4 \\
\hline Creative arts centers & 27 \\
\hline Complexes of tourist cottages & 30.6 \\
\hline Camping sites & 25.8 \\
\hline
\end{tabular}




\begin{tabular}{|l|c|}
\hline Category of the accommodation establishment & Share (in \%) \\
\hline Tent camp sites & 16 \\
\hline Hostels & 48.7 \\
\hline Health establishments & 78 \\
\hline Rooms for guests & 22.6 \\
\hline Agro-tourism lodgings & 12.5 \\
\hline Other not classified & 28.1 \\
\hline
\end{tabular}

Source: Statistics Poland (2016, p. 200)

It is worth mentioning that as far as the tourist use of any type of accommodation units is concerned, these are the health units which are the most often used by their clients (close to $80 \%$ in 2015). This trend even doubles for the average score for the country and also in the category of 'other facilities' to which the 'health establishments' belong. The 'hostels' are second (approx. 48\%) and 'holiday youth centers' third (just $42 \%$ of usage). The hotels, which are the most important in the category of bed numbers, are the fourth with $39 \%$ of the occupancy rate. Such a score shows the importance of the health services for the tourist market in the country.

In all the types of establishments in 2015, almost 27 million tourists were accommodated. In this group 719, 818 persons used the health establishments.

Figure 3 Tourists in the health establishments according to the individual months in 2015

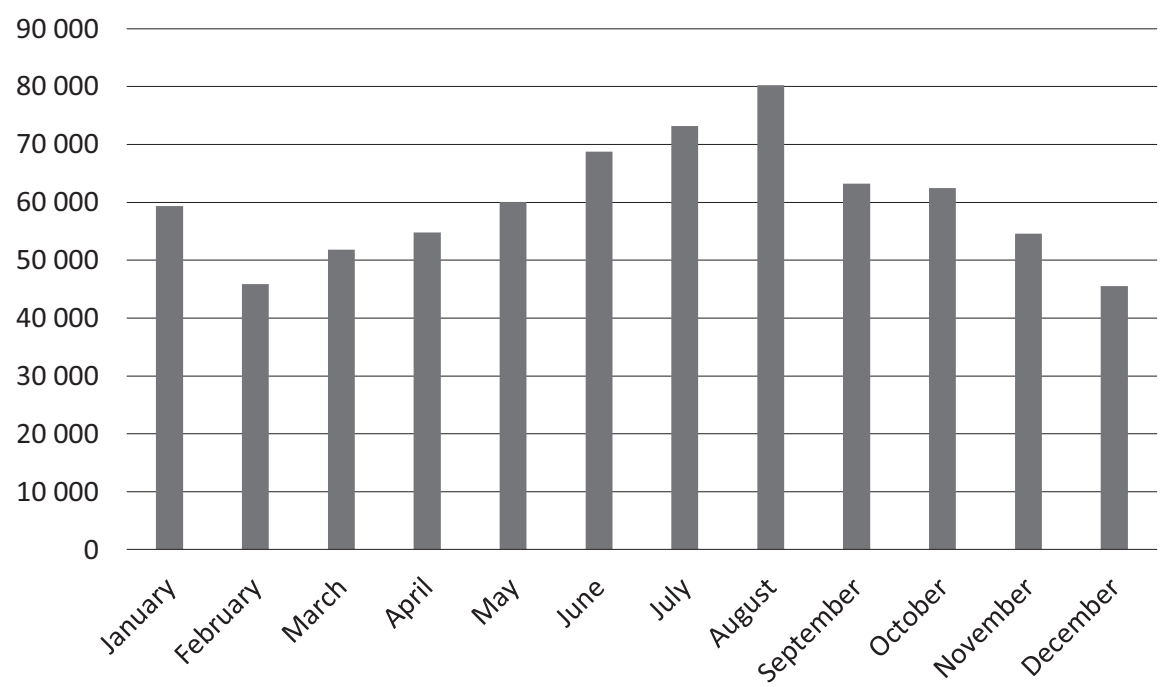

Source: Statistics Poland (2016, p. 201) 
Concentration of tourists can be observed in both holiday months, which is August (63,200 tourists) and July (slightly more than 73, 000 of persons). The less popular months are February and December with around 45,000 visitors. In the case of foreign tourists in the health establishments, the number of tourists is considerably smaller - just 39,332 persons. The monthly distribution is slightly different than in case of all tourists. The most popular months are August (5,068 persons) and September (5,203 persons). The least popular months are January (1,276 persons) and November (1,579 persons).

Finally, the number of tourists in the health establishments divided by months shows the specifics of spa tourism.

Figure 4 Tourists in the health establishments by voivodship, 2015

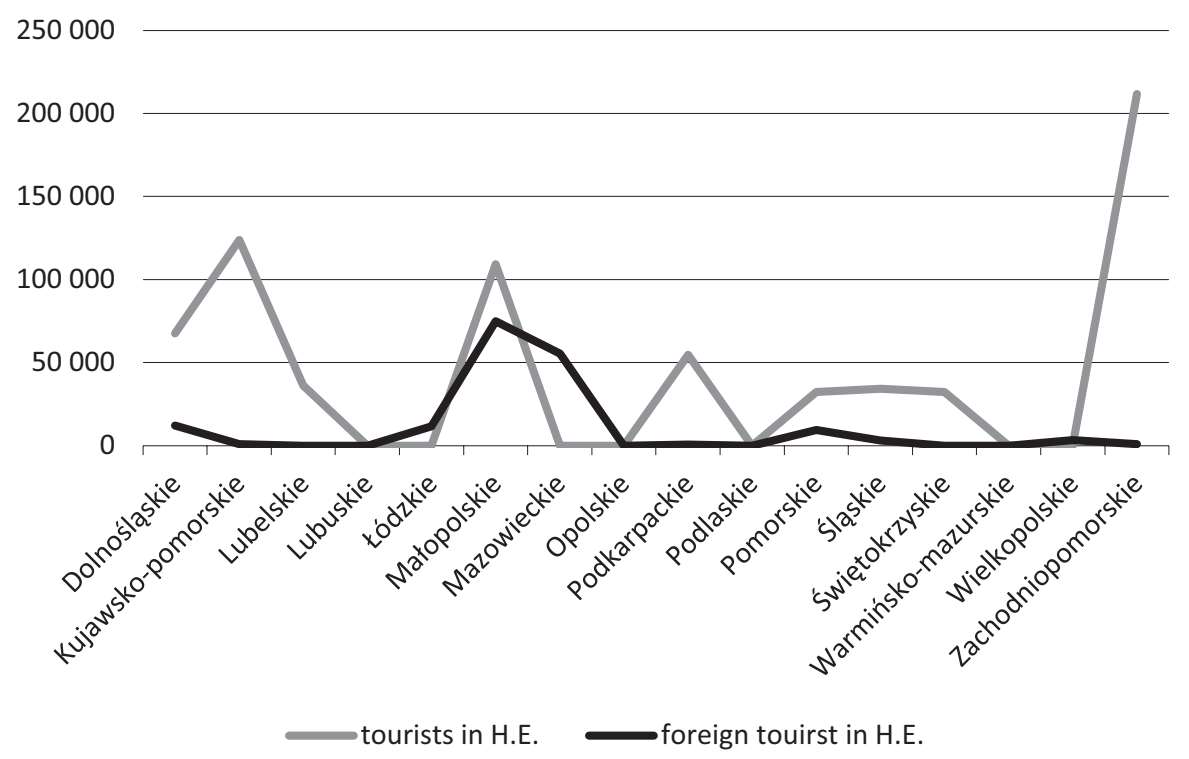

Source: Statistics Poland (2016, p.213)

The most visited regions in Poland in 2015 were mazowieckie and małopolskie regions - in both cases, the number of visitors exceeded 4 million. Dolnoślaskie region was the third with 2.6 million tourists. More than two million tourists were also registered in pomorskie, zachodniopomorskie and śląskie voivodships. However, as for the spa tourists, the highest number is observed in zachodniopomorskie (211 771), kujawskopomorskie (123 777) and małopolskie (109 124) regions. In the case of foreign tourists in the health establishments, the three most visited regions were: małopolskie, mazowieckie and dolnoślaskie. Surprisingly, the number of foreign tourists in zachodniopomorskie did not exceed 1,000 persons.

The health tourism establishments at present are well equipped and may compete with the European offer. Each year its importance for the attraction of the new-spa-tourists 
increases, and many data confirms it. The spa accommodation units are the strengths in the complex spa offer in Poland.

\section{Conclusions}

The access to the European Union has created favorable conditions and served as a good excuse for the new directions of the spa resorts development in Poland. In many European countries, the interest in the treatment with the natural resources use increases. It is caused not only by the demographical situation in the aging society, but also by the growth of health awareness. Such a situation is a good starting point for the development of the spa offer in the spa resorts. But to succeed in this field, well-defined strategies should be set. Among them the most important ones would be:

- extension and differentiation of the treatment programs in the spa resorts,

- modernization of the existing spa infrastructure with the use of the European funds,

- development of the scientific activity that would support the sustainable development of the spa resorts,

- implementation of the new marketing techniques,

- implementation of the additional offer to the treatment services,

- development of the tourists' and active relaxation function in the spa resorts,

- use of the cultural material and non-material potential for the development of the supporting offer.

The problem is still quite a static treatment offer, which is similar in each spa resort, even if it has at its disposal different natural resources. However, a chance for success exists. It depends on the shape of the offer. Each spa resort should focus its efforts on the differentiation of the programs and preparation and promotion of unique proposals based on unique resources it has at its disposal. Such an approach is an important issue in the promotion of the region.

Another important issue for the development of the existing spa treatment offer is the extension of spa products with wellness, which is clearly visible in the European spas. The traditional spas in order to attract clients-tourists should be open to new alternative treatments that would support the classic health cure. These might include, for example, a therapy by music, colorful lights or other similar ideas. At the same time, the tourist and health infrastructure such as hotels should be improved since the quality is one of the most important element of the well prepared complex spa tourist product.

At present, the holistic approach to the potential of the spa resorts is the leading one. Thanks to attractive localization and long tradition, the spas in Poland are usually very popular among tourists because of the spa cultural and natural potential. Thanks to this, the Polish spas have become cultural centers with their material resources and cultural tradition, as well as a place for active recreation in an attractive natural landscape. 
The multiplicity of tourist values, natural resources and existing infrastructure accompanying the clients, attractive products, or security makes the spa resorts of Poland an important trade mark tourist product which can compete both at the regional and international level.

\section{References}

Act of 28 July 2005, No 167, 1399 on spa treatment, spas and protection areas health resort and spa communities. (Dz.U. 2005, nr 167, poz. 1399, Ustawa z dnia 28 lipca 2005 r. o lecznictwie uzdrowiskowym, uzdrowiskach i obszarach ochrony uzdrowiskowej oraz gminach uzdrowiskowych). Retrieved from http://prawo.sejm.gov.pl/isap.nsf/download.xsp/WDU20051671399/T/ D20051399L.pdf.

Balińska, G. (1991). Uzdrowiska dolnoślaskie (Dolnoślaskie Spas). Wroclaw, Poland: Wydawnictwo Politechniki Wrocławskiej.

Dąbrowska-Zielińska, K., \& Wołk-Musiał, E. (2012). Turystyka uzdrowiskowa w Polsce i na świecie perspektywy rozwoju spa i wellness w Polsce (Spa tourism in Poland and in the world - perspectives of spa and wellness development in Poland). Inżynieria Ekologiczna, 13(30), 36-47.

Dryglas, D. (2006). Ksztattowanie produktu turystycznego uzdrowisk w Polsce (Shaping the tourist product of spas in Poland). Krakow, Poland: Wydawnictwo Uniwersytetu Jagiellońskiego.

Hadzik, A. (2007). Wybrane uwarunkowania rozwoju turystyki uzdrowiskowej w Polsce (Selected determinants of the development of spa tourism in Poland). Studia nad turystyka. Prace ekonomiczne i spoteczne (pp. 53-62). Krakow, Poland: IGiGP Uniwersytet Jagielloński.

Iwanek, T., \& Widawski, K. (2007). Model funkcjonowania turystyki w miejscowości uzdrowiskowej na przykładzie Vichy (The model of functioning of tourism in a spa town on the example of Vichy). In J. Wyrzykowski (ed.), Uwarunkowania rozwoju turystyki zagranicznej w Europie Środkowej $i$ Wschodniej, Vol. 9, Wspótczesne modele turystyki uzdrowiskowej w kontekście zrównoważonego rozwoju (Contemporary models of health tourism in the context of sustainable development) (pp. 165178). Wroclaw, Poland: Instytut Geografii i Rozwoju Regionalnego, Uniwersytet Wrocławski.

Jagusiewicz, A. (2002). Infrastruktura turystyki uzdrowiskowej w Polsce (Infrastructure of spa tourism in Poland). Warszawa, Poland: Instytut Turystyki.

Januszewska, M. (2004). Znaczenie produktu uzdrowiskowego w rozwoju turystyki w Polsce (The importance of a spa product in the development of tourism in Poland). In A. Panasiuk (ed.), Markowe produkty turystyczne. Szczecin, Poland: Uniwersytet Szczeciński.

Kalda, G., \& Lalicka, M. (2014). Stan i perspektywy rozwoju bazy uzdrowiskowej w Polsce (The condition and prospects for the development of the spa base in Poland). Czasopismo inżynierii ladowej, środowiska $i$ architektury, 31(61), 85-100.

Karbowiak, K. (2015). Perspektywy rozwoju turystyki uzdrowiskowej w Polsce (Prospects for the development of spa tourism in Poland). Europa Regionum, 19(24), 233-248.

Kraś, J. (2011). Istota i znaczenie turystyki uzdrowiskowej w Polsce (The essence and importance of spa tourism in Poland). Seminare. Poszukiwania naukowe 29, 151-162.

Łęcka, I. (2003). Nowe (?) trendy w turystyce zdrowotnej (New (?) Trends in health tourism). In A. Kowalczyk (ed.), Geografia turyzmu, Prace i Studia Geograficzne (pp. 173-190). Warszawa, Poland: WGiSR, Uniwersytetu Warszawskiego.

Lewandowska, A. (2007). Turystyka uzdrowiskowa (Spa tourism). Szczecin: Uniwersytet Szczeciński. 
Łopaciński, K. (2003). Tworzenie regionalnych i lokalnych produktów turystycznych i dostosowanie produktów do sytuacji rynkowej (Creating regional and local tourist products and adjusting the products to the market situation). In Ksztattowanie produktu turystycznego jako czynnika aktywizacji gospodarczej regionów $i$ spoteczności lokalnych (Shaping the tourist product as a factor of economic activation of regions and local communities). Warszawa, Poland: Polska Organizacja Turystyczna.

Małecka, B., \& Marcinkowski, J. (2007). Rys historyczny rozwoju lecznictwa uzdrowiskowego Historical outline of the development of spa treatment). Probl. Hig Epidemiol, 88(2), 139-142.

Mika, M., \& Pawlusiński, R. (2007). Wybrane problemy rozwoju usług zdrowotnych spa i wellnes w polskich Karpatach (Selected problems related to the development of health services spa and wellness in the Polish Carpathians). In J. Wyrzykowski (ed.), Uwarunkowania rozwoju turystyki zagranicznej w Europie Środkowej $i$ Wschodniej, Vol. 9, Wspótczesne modele turystyki uzdrowiskowej w kontekście zrównoważonego rozwoju (Contemporary models of health tourism in the context of sustainable development) (pp. 63-72). Wroclaw, Poland: Instytut Geografii i Rozwoju Regionalnego, Uniwersytet Wrocławski.

Ministry of Health (Ministerstwo Zdrowia). (2017). Wykaz uzdrowisk wraz z kierunkami leczniczymi (List of spas with therapeutic directions). Retrieved June 10, 2017 from http://www.mz.gov.pl/wpcontent/uploads/2015/04/wykaz.pdf.

Notice of April 24, 2012 regarding the publication of a uniform text of the Act on spa treatment, spas and protection areas health resort and spa communities (Dz. U. z 2012 r., pos. 651, Obwieszczenie Marszałka Sejmu Rzeczypospolitej Polskiej z dnia 24 kwietnia 2012 r. w sprawie ogłoszenia jednolitego tekstu ustawy o lecznictwie uzdrowiskowym, uzdrowiskach i obszarach ochrony uzdrowiskowej oraz o gminach uzdrowiskowych). Retrieved from http://www.prawo.egospodarka.pl/ akty/pliki/dziennik-ustaw/2012/000/651/pdf.

Paprzycka, A. (2007). Zarys historii rozwoju przestrzennego uzdrowiska Lądek Zdrój (An outline of the history of spatial development of the Lądek Zdrój health resort). In J. Wyrzykowski (ed.), Uwarunkowania rozwoju turystyki zagranicznej w Europie Środkowej i Wschodniej, Tom 9, Wspótczesne modele turystyki uzdrowiskowej w kontekście zrównoważonego rozwoju Contemporary models of health tourism in the context of sustainable development) (pp. 227-238). Wroclaw, Poland: Instytut Geografii i Rozwoju Regionalnego, Uniwersytet Wrocławski.

Płonka-Syroka, B., \& Kaźmierczak, A. (2012). Historia kultury uzdrowiskowej w Europie. Kultura uzdrowiskowa w Europie (History of spa culture in Europe. Spa culture in Europe). Wroclaw, Poland: Wydawnictwo Arboretum.

PN-2001 / Z-11000 (2001) Polish Norm. Spas - Terminology, classification and general requirements. Warsawa, Poland: Polish Committee for Standardization.

Ponikowska, I. (2009). Tradycja, nowoczesność i innowacyjność w lecznictwie uzdrowiskowym naszych czasów (Tradition, modernity and innovation in spa treatment of our time). In J. Golba \& K. Rymarczyk-Wajda (eds.), Innowacyjne kierunki rozwoju turystyki uzdrowiskowej i lecznictwa uzdrowiskowego (Innovative trends in the development of spa tourism and spa treatment) (pp. 15-22). Krynica-Zdrój, Poland: Stowarzyszenie Gmin Uzdrowiskowych RP.

Rapacz, A., \& Jaremen, D. (2013). Znaczenie usług spa \& wellnes w budowaniu przewagi konkurencyjnej przedsiębiorstw hotelarskich - case study hoteli uzdrowiskowych w Świeradowie-Zdroju (The importance of spa \& wellness services in building a competitive advantage of hotel enterprises - a case study of spa hotels in Świeradów-Zdrój). Ekonomiczne problemy turystyki, 3(23), Zeszyty naukowe nr 784, 107-123.

Statistics Poland (Główny Urząd Statystyczny). (2016). Turystyka w 2015 (Tourism in 2015). Warszawa, Poland: Author. 
Szromek, A. (2007). Turystyka w polskich uzdrowiskach i prawne uwarunkowania jej rozwoju (Tourism in Polish spas and legal conditions for its development). Zeszyty naukowe. Organizacja i Zarzadzanie, Politechnika Ślaska, 40, 267-287.

Szymańczyk, J., \& Wróbel, E. (2007). Oferta turystyki uzdrowiskowej w Zespole Uzdrowisk Kłodzkich (The offer of spa tourism in the Kłodzko Spas). In J. Wyrzykowski (ed.), Uwarunkowania rozwoju turystyki zagranicznej w Europie Środkowej i Wschodniej, Vol. 9, Wspótczesne modele turystyki uzdrowiskowej w kontekście zrównoważonego rozwoju (Contemporary models of health tourism in the context of sustainable development) (pp. 295-300). Wroclaw, Poland: Instytut Geografii i Rozwoju Regionalnego, Uniwersytet Wrocławski.

Toczek-Werner, S., \& Sołtysik, M. (2007). Wykorzystanie czasu wolnego przez polskich i francuskich kuracjuszy odwiedzających uzdrowisko Świeradów Zdrój (The use of free time by Polish and French visitors visiting the spa Świeradów Zdrój). In J. Wyrzykowski (ed.), Uwarunkowania rozwoju turystyki zagranicznej w Europie Środkowej i Wschodniej, Vol. 9, Wspótczesne modele turystyki uzdrowiskowej w kontekście zrównoważonego rozwoju (Contemporary models of health tourism in the context of sustainable development) (pp. 251-260). Wroclaw, Poland: Instytut Geografii i Rozwoju Regionalnego, Uniwersytet Wrocławski.

Widawski, K. (2007). Folklor i obiekty materialnej kultury ludowej jako składnik oferty komplementarnej na przykładzie polskich uzdrowisk (Folklore and objects of material folk culture as a component of the complementary offer on the example of Polish spas). In J. Wyrzykowski (ed.), Uwarunkowania rozwoju turystyki zagranicznej w Europie Środkowej $i$ Wschodniej, Vol. 9, Wspótczesne modele turystyki uzdrowiskowej w kontekście zrównoważonego rozwoju (Contemporary models of health tourism in the context of sustainable development) (pp. 165-178). Wroclaw, Poland: Instytut Geografii i Rozwoju Regionalnego, Uniwersytet Wrocławski.

Wyrzykowska, M. (2007). Stan zachowania historycznej architektury w uzdrowiskach dolnośląskich (The condition of historical architecture in Lower Silesian health resorts). In J. Wyrzykowski (ed.), Uwarunkowania rozwoju turystyki zagranicznej w Europie Środkowej $i$ Wschodniej, Vol. 9, Wspótczesne modele turystyki uzdrowiskowej w kontekście zrównoważonego rozwoju (Contemporary models of health tourism in the context of sustainable development) (pp. 117-128). Wroclaw, Poland: Instytut Geografii i Rozwoju Regionalnego, Uniwersytet Wrocławski.

Wyrzykowski, J., Marak, J., Sołtysik, M., Oparka, S., \& Zajączkowski, J. (2007). Rola turystyki uzdrowiskowej w gospodarce Dolnego Slaska (The role of spa tourism in the economy of Lower Silesia). In J. Wyrzykowski (ed.), Uwarunkowania rozwoju turystyki zagranicznej w Europie Środkowej $i$ Wschodniej, Vol. 9, Wspótczesne modele turystyki uzdrowiskowej w kontekście zrównoważonego rozwoju (Contemporary models of health tourism in the context of sustainable development) (pp. 397-410). Wroclaw, Poland: Instytut Geografii i Rozwoju Regionalnego, Uniwersytet Wrocławski. 